\title{
Major Sorghum Production Constraints and Coping Mechanisms: The Case of Anthracnose (Colletotrichum sublineolum)
}

\author{
Kebede Dessalegn ${ }^{1,2, a, *}$, Peter Ogbonna ${ }^{1, b}$, Christian Agbo $^{1, c}$, Dagnachew Lule $^{2, d}$ \\ ${ }^{1}$ Department of Crop Science, University of Nigeria, P.O. Box 3236, Street Nsukka 41001, Enugu State, Nigeria. \\ ${ }^{2}$ Oromia Agricultural Research Institute (IQQO), Ethiopia, P.O. Box 81265, Addis Ababa, Ethiopia
}

*Corresponding author

A R T I C L E IN F O A B S T R A C T

Review Article

This paper attempts to review the major sorghum production constraints, the progress and perspective on sorghum anthracnose (Colletotrichum sublineolum) resistance breeding. The importance of anthracnose in sorghum production and breeding for resistance status and progress were also primly discovered. Sorghum is an ancient environment resilient crop and believed to be

Received : $13 / 08 / 2020$

Accepted : 25/02/2021 a future crop due to its important merits like tolerant to stresses, wide adaptability and low input requirement. Insects and disease are major biotic impediments to realizing the yield potential of the crop. Anthracnose disease caused by Colletotrichum sublineolum is the most important disease that severely affecting the crop in all sorghum producing regions of the world. Research results revealed that anthracnose resulted in $30-50 \%$ or greater yield losses. Several management strategies such as,

Keywords:

Anthracnose

Genetic resource

Host-plant resistance

Stress

Susceptible cultural, chemical and using resistance varieties have been developed. Employing host-plant resistance is the most economical and environmentally friendly approach which can successfully control the disease. Breeding assisted with molecular markers plays a great role in resistance breeding programme as it makes easy to screen large number of genotypes at once. Recent advancement of molecular breeding and bio-informatics tools are playing a significant role in efficiencies and precisions of resistance breeding. QTLs or genomic area for resistance were identified using traditional molecular markers and recent research results revealed discoveries of specific gene and locus using high throughput markers like SNPs using GWAS approach. The discovery of genes/QTL associated with the resistance trait, using the high through put molecular markers like SNPs, facilitates the easiest way for gene pyramiding from different individual genotypes to a single variety, introgression into adapted elite cultivar through marker assisted and editing genes for elite landraces to develop durable resistance varieties. Transgenic approach is now a day becoming a powerful tool to utilize novel alien genes for crop improvement including anthracnose resistance breeding in sorghum. \footnotetext{
$\begin{array}{ll}\text { kebelem@gmail.com } & \text { (i) https://orcid.org/0000-0003-2553-3674 } \\ \text { christian.agbo@unn.edu.ng } & \text { (iD) https://orcid.org/0000-0003-3059-3903 }\end{array}$

b@peter.ogbonna@unn.edu.ng hawinok@gmail.com

\section{Introduction}

World is in challenge to feed the sharply increasing human population which is expected to exceed 9 billion by 2050 and will reach 11.2 billion in 2100 (FAO, 2009; UNDESA, 2017). There are predictions that suggests an increase in global land use efficiency with tripling of the international trade in 2050 to satisfy food demands of about 9.8 billion world population using the existing cropping land area (Pastor et al., 2019). This need may mainly be achieved through increasing yields on existing crop land (Foulkes et al., 2011), particularly by growing the crops that can potentially adapted well and tolerant to biotic and a biotic stress that limits crop yields as it is very difficult to find stress free areas where crops may achieve their potential yields (Boyer, 1982).

A large land mass coverage about 3 billion ha in Africa, of which 1.3 billion hectares are agricultural land, out of which only 252 million ha $(19.36 \%)$ has been cultivated (FAO, 2011). Africa is the center of origin and source of many cereals and is the major producer of cereal crops including Sorghum, millet, teff, barley, African rice and so on (Vavilov, 1992). Under the current changing climatic scenarios, drought tolerant crops like sorghum [Sorghum bicolor (L.) Moench] received due importance and expected to have renewable benefits as a climate-resistant crop. 
Sorghum (Sorghum bicolor L. Moench) is the world's fifth most important cereal, both in terms of production and area planted (Anonymous., 2006; Mace et al., 2013). It is exceptionally one of the best adapted crop to drought-prone areas (Ng'uni et al., 2011; Burrell et al., 2015) and a crop of major importance in semi-arid tropical regions of the world (Smith and Frederiksen, 2000). Reports indicated more than 105 countries are cultivating sorghum and among these, United States, India, Mexico, Nigeria, Sudan, Ethiopia, Australia, Brazil, China, and Burkina Faso are the top 10 sorghum producers (Sujay Rakshit et al., 2014).

The drought resilience and relatively minimal production inputs requirement of sorghum in comparison of many cereals such as Corn, Wheat and others makes the crop very important (Lobell et al., 2008; Rooney et al., 2008). It has been reported, sorghum naturally required only one-half to two-thirds the amount of rainfall as maize (Hancock, 2000). Although the crop is one of the largest economies in the world. The increasing frailer of other crops in the risk of current climate change and the crop's ability to survive makes it more preferred and plays an important role in sustainable food security, especially in rural Africa (Vincent et al., 2013).

Sorghum (S. bicolor (L.) Moench) diploid $2 n=2 x=20$ with genome size of $730 \mathrm{Mb}$ (Paterson et al., 2009), a member of the grass family Poaceae (Clayton and Renovoize, 1986; Paterson et al., 2009). The Sorghum genus is highly varied in geographic, morphological and genetic, and has approximately 25 known species that are classified into five taxonomic sections, namely Eusorghum (containing the domesticated species), Chaeto sorghum, Hetero sorghum, Para sorghum and Stipo sorghum (Garber, 1950; USDA-NASS, 2012). Sorghum bicolor is a highly diverse cereal composed of five botanical races (Bicolor, Durra, Caudatum, Guinea and Kafir) distinguish in different types of inflorescence (Harlan and Dewet, 1972). Thus, the objective of this paper is to review mechanism of host plant resistance; efforts, progress and perspective of anthracnose resistance breeding in sorghum. Sorghum economic importance, production constraints, global production and spread, available genetic resources and improvement of sorghum were the main focuses.

Global distribution and economic importance of sorghum

Sorghum is an ancient crop (Mann et al., 1983), the origin and early domestication of sorghum took place in north-eastern Africa, north of the Equator and east of $10^{\circ} \mathrm{E}$ latitude, about 5,000 years ago (Wendorf et al., 1992; Dahlberg and Wasylikowa, 1996). Following early domestication, sorghum spread throughout Africa and Asia by trading and migratory path. It has been selected and dispersed throughout a wide range of environments and utilization giving rise to a widely adapted genetic base that has been further exploited throughout the agricultural process to create the current crop known as cultivated sorghum (Esele, 1995; Doggett, 1988; Dahlberg et al., 2011). Recent genetic studies reviled different domesticated races may have undergone multiple independent domestications actions (Lin et al., 2012). Sorghum cultivation is spread out across the globe and more than 100 countries grown sorghum globally, in Asia, Sub-Saharan Africa, in the United States and Mexico in
North America, South American and European countries and also in Australia (Deb et al., 2004). More than half of the world is cultivating sorghum in semi-arid zones, where it is a staple food for millions of poor and hungry people (Mehmood et al., 2008). The origin and spread of the races of Sorghum bicolor across the world (Figure 1) illustrated below

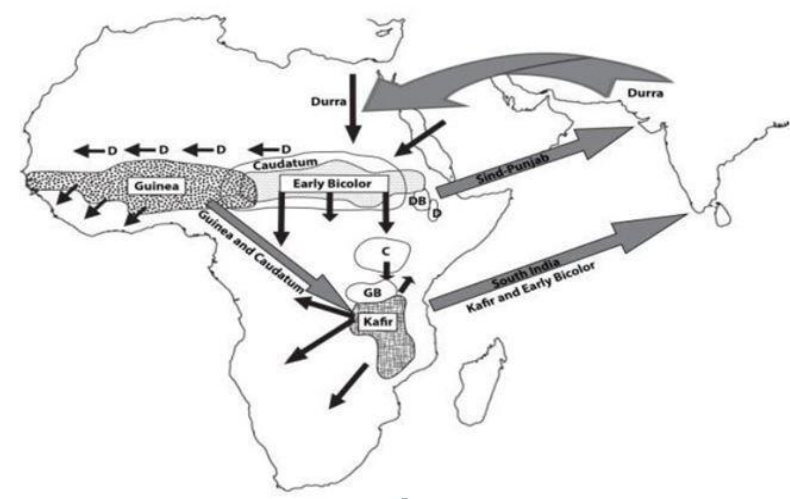

Figure 1. The origin and spread of the races of Sorghum bicolor around the globe

(Source: OECD. 2016; Olsen K.M., 2012).

Sorghum is an economically very important $\mathrm{C} 4$ grass grown for grain, forage, sugar/syrup, brewing, and lignocelluloses biomass production for bio-energy. (Ejeta and Grenier, 2005; Mullet et al., 2014; Ort et al., 2015; Luis and Jeffrey, 2019). In developing countries, beside the grain as food, sorghum by-products are also very important and used for feed, cooking fuel, construction materials, and as physical support for vining crops like yams (NRC, 2004; Reddy et al., 2005). Sorghum is particularly essential crop in Africa, second to maize, as staple grain for millions of people. Although it is mainly consumed as a grain, and also prepared into a wide variety of other food products such as porridges, breads, lactic and alcoholic beverages, and weaning meals (Mejia and Lewis, 1999; Batey, 2017; Adebo et al., 2018).

\section{Sorghum production overview}

Sorghum is globally cultivated in 41 million hectare with grain production of 64.20 million tons. Of this, about 26 million tons is produced in Africa. The major production areas including the great plains of North America, Sub-Saharan Africa, Northeast China, and the Deccan plateau of central India (Vijayakumar et al., 2014). More than $90 \%$ of total global sorghum harvested areas are in Africa and Asia (Bhagavatula et al., 2013; Deb et al., 2004); Africa accounting for $61 \%$ of the area and $41 \%$ of production followed by the Americas (38\%) and Asia accounts for $22 \%$ of the area and $18 \%$ of production (Bhagavatula et al., 2013).

\section{Genetic diversity in sorghum}

A diverse genetic resource is pre-requisite for breeding of crop varieties and crop species having a narrow genetic diversity/bases are susceptible to emerging pathogens or other constraints leading to loss of productivity (Glaszmann et al., 2010; Dyer et al., 2014). Exploitation of genetic variation is the basis for any crop improvement 
programme. Information about germplasm diversity and genetic relatedness among elite breeding material is a fundamental element in plant breeding (Wilfred, 2008; Sanwal et al., 2015). Information about the genetic variations present within and between various plant populations and their structure and level can play a beneficial role in the efficient utilization of plants genetic resources (Cole CT, 2003). Genetic variation results from changes in DNA sequence and is the basis for evolution. In the simplest case, variation in DNA sequence will result in variation in the amino acid sequence of the protein encoded by that gene (Wilfred Vermerris, 2008).

Sorghum is a very genetically diverse crop both in cultivated and wild species (Iqbal et al., 2010). The greatest variation within the sorghum genus is found in EthiopiaSudan (north-east Africa) where it is likely to have originated (OECD, 2016). Gezahegn et al. (2019) reported Ethiopian Sorghum Landrace Collection, and the surrounding east African regions have high genetic diversity and the germplasm harbor enormous genetic variations. Ethiopian sorghum accessions are known in possessing novel traits such as better agronomic performance, variable maturity groups, high lysine, good grain quality, resistance to disease and insect pests and stay green that could be utilized in improved cultivar development (Kebede, 1991). Erpelding (2010) and Cuevas et al. (2019) reported that Ethiopia is an important center of genetic diversity for sorghum, and have been widely used in grain sorghum breeding programs in the United States and the germplasm served as a source of genetic resource for host-plant resistance to anthracnose and several photoperiod-insensitive lines development.

\section{Sorghum genetic resources}

Plant Genetic resource is the genetic materials of plants that are resources of present and future generation (IPGRI, 1983). Sorghum has an enormous ranges of genetic variability available in Africa where domestication first occurred and further diversity also occurred in Asia because of the early introduction of the crop (Rosenow and Dahlberg, 2000). Sorghum genetic resource is conserved in many countries around the world and approximately about 168500 accessions of sorghum germplasm collections are available globally (Reddy et al., 2006). The major organization or/and country which maintain sorghum genetic resources are: International Crop Research Institute at Semi-Arid Tropics (ICRISAT) found in India; the national plant Germplasm system (NPGS) in USA; Ethiopia; Sudan; South Africa; India and China mainly because of having a large crop improvement programs (Rosenow and Dahlberg, 2000).

Currently, ICRISAT is the main repository for world sorghum germplasm with a total of about 36,774 accessions collected from 91 countries and this collection is estimated to present about $80 \%$ of the variability found in sorghum (Eberhart et al., 1997). Ethiopia has a wealth of genetic resources for sorghum and has contributed for the global germplasm pools and sources of genes for important traits like stay green and midge resistance (Esele, 1995; Doggett, 1988; Reddy et al., 2009). In spite of the ample genetic resources, the productivity of sorghum is affected by several biotic and abiotic constraints (Rao et al., 2004; Berenji and Dahlberg, 2004).

\section{Abiotic Stresses}

While demands of crop products are increasing following the world population increment, the productivity is threatened by various stress factors associated with global climate change (Zhao et al., 2017; Challinor et al., 2014). There are several of abiotic constraints significantly affecting sorghum production and productivity.

Drought is one of the most serious environmental stresses across the world, affecting plant growth and development and, consequently, the yields and productivity of crops (Miao et al., 2017). It is the primary crop production limiting factor aggravating food security problem worldwide among abiotic stresses followed by soil acidity (VonUexktill \& Mutert, 1995). Different authors reported different level of grain reduction at different growth stages when drought occurred and it is vital to explore the different growth stages (Prasad et al., 2008).

Aluminum toxicity: remains the major food security problem worldwide next to drought stress among abiotic constraints on crop production (VonUexktill \& Mutert, 1995). More $20 \%$ of the arable lands in sub-Saharan Africa, East Asia and North America; $38 \%$ of the farmland in Southeast Asia and 31\% of Latin America were affected in Al toxicity (Wood et al., 2000). Crop yields are significantly reduced by aluminum toxicity on highly acidic soils, which comprise up to $50 \%$ of the world's arable land (Kochian, 1995, Wood et al., 2000). There are two major categories of aluminum toxicity effects in plants: morphological and physiological. Morphological effects refer to the visual symptoms and damage occurring in different root tissues; whereas, the physiological effects refer to changes in metabolism and function of plants and the resultant consequences (Bian et al., 2013).

Salinity (saline and sodic) soils, has long been a major constraint on crop Szabolcs, 1994; Shannon, 1997; Rohila et al., 2002). Approximately more than 800 Million ha globally affected by salinity (FAO, 2000; Turkan and Demiral, 2009; Munns, 2005). It is one of the major abiotic stress that affect crop productivity, especially in arid and semi-arid tracts as well as coastal areas in tropical regions of the world (Hafsi et al., 2010). Salt accumulation is mainly related to a dry climate as this area appeared where the sorghum crop is cultivated and affects the productivity of the crop (Almodares et al., 2008).

\section{Biotic Stresses}

Any plants stress by Living organisms cause both pre and post-harvest losses and unlike abiotic, directly deprives their host nutrients leading to reduced plant vigor even death of the host plant at extreme case (Singla and Krattinger, 2016). In sorghum, the biotic stresses include damages caused by pathogens, insect pests, birds, rodents and parasitic weeds (Berenji and Dahlberg, 2004). Diseases and insects are major impediments to realizing the high yield potential of sorghum cultivars (Sharma et al., 2012). Among diseases of sorghum, anthracnose caused by Colletotrichum sublineolum (P. Henn.in Kabat and 
Bubak), is one of the most important disease limiting productivity in most sorghum growing regions worldwide (Hulluka and Esele, 1992; Mathur et al., 2002; Alemayehu et al., 2010; Burrell et al., 2015).

\section{Anthracnose}

Anthracnose disease caused by Colletotrichum species, which affects over 42 genera of plants in the family Poaceae and other members of plant families (Kelly and Allejo, 2004; Crouch and Beirn, 2009; Hussain and Abid, 2011). It is one of the most devastating disease affecting sorghum production and productivity in all parts of the world (Singh et al., 2006; Anonymous, 2006; Perumal et al., 2009; Li et al., 2013). The disease was first reported in Togo in 1902 (Stoop et al., 1982; Thakur and Mathur, 2000), West Africa and spread to different African countries. Later observed in all sorghum growing areas of the world (Burrell et al., 2015; Costa et al., 2015; Patil et al., 2017). Anthracnose is among the disease of primary important in sorghum producing areas of the world (Doggett, 1988; Marley et al., 2005; Alemayehu et al., 2010) and it has also been reported as one of the most important disease infecting sorghum in East African countries including Ethiopia and Kenya (Ngugi et al., 2002; Alemayehu et al., 2010). It has been reported that the disease pressure is very high in West and Central Africa (Marley et al., 2001).

\section{Dissemination, infection, and survival mechanism of the pathogen}

Understanding the complex life style patterns of Colletotrichum spp. and the dynamic state of their interactions with their hosts has important implications for disease control and breeding programme (Newton et al., 2010; Bourget et al., 2013). Transmission of $C$. sublineolum from plant to plant is through the transfer of falcate-shaped, asexual conidia, a process which is primarily dependent on water splash and blowing raindrops (Viswanathan and Samiyappan, 2001; Murphy et al., 2008). Acervuli are formed from necrotic plant tissue and these structures produce numerous falcate-shaped conidia serves as a source of secondary inoculum in the disease cycle (Panaccione et al., 1989). Conidia and conidial germlings produce an extracellular matrix composed of mannose and heavily glycosylated glycoproteins that permit adhesion to on hydrophobic surfaces. Fastening of conidia to host leaves prevent the spores from being washed away by rain, allowing germ tube formation and increased disease development (Sugui et al., 1998; Wharton and Schilder, 2008).

Colletotrichum sublineolum overwinters in the soil and decaying plant residues and seeds as mycelium, acervuli, melanizedhyphopodia, sclerotia and micro-sclerotia (Sukno et al., 2008; Crouch and Beirn, 2009). C. sublineolum is capable of surviving on crop debris for 18 months (Casela \& Frederiksen, 1993), and survives in sorghum seeds at room temperature for up to 2.5 years (Mishra, 1957). Diagrammatic illustration of Colletotrichum Sps Survival, life cycle and infections as follows (Fig: 2)

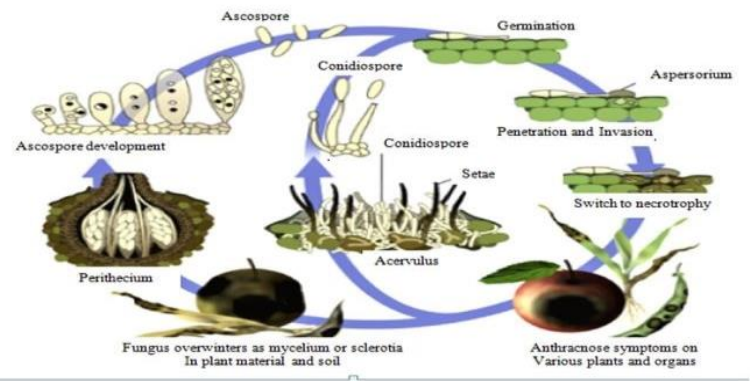

Figure 2. Life cycle and overwinters of Colletotrichum (Source: Silva et al., 2017)

\section{Economic Importance of Anthracnose}

Anthracnose caused by Colletotrichum sublineolum Hann. Kabát et Bub, is the most devastating sorghum disease and is a major limiting factor in sorghum production (Marley et al., 2001; Valerio et al., 2005; Sharma et al., 2012). Anthracnose disease is considered to be a limiting factor globally in sorghum production and can infect all above ground (leaves, stalks, panicles and seeds) while exhibiting extreme variability in terms of pathogenicity to host cultivars (Tesso et al., 2011).

Anthracnose weakens the plant, severely reducing grain yield and quality. Reports showed grain yield losses range from 30 to $67 \%$ ( Harris et al., 1964; Ali et al., 1987, Thomas et al., 1996, Thakur et al., 2007 ) also reported grain yield loss up to $30-50 \%$ caused by the panicle phase of anthracnose. Susceptible cultivars have been reported to experience losses as high as 50\% (Harris et al., 1964; Thomas et al., 1996, Chala et al., 2010).

The disease is more prevalent and severe in warm and humid environments, where it causes substantial economic losses. The pathogen causes seedling blight, leaf blight stalk rot, head blight, and grain molding and, thus, limits both forage and grain production. Among these, foliar anthracnose is the most pronounced and devastating on forage and grain sorghum, especially on sweet sorghum cultivars (Thakur and Mathur, 2000; Chala et al., 2010)

\section{Mechanism of Host-plant Resistance}

In order to survive, plants developed a broad range of defense mechanisms against potential pathogens. These defense mechanisms are mainly based on avoidance, resistance or tolerance. Resistance mechanisms are by far the most important defense mechanisms employed by host plants, while avoidance and tolerance play a minor role (Parlevliet, 1989). Defense systems often depend on the combination of a specific set of dominant $R$ genes in the plant and a corresponding set of dominant avirulence (Avr) genes in the pathogen (Flor, 1971; Keen, 1990). Expression of the Avr genes triggers plant defense responses governed by the product of the $\mathrm{R}$ gene (Bogdanove, 2002). This gene-for-gene resistance strategy underlies the molecular basis of defense systems in plants (Flor, 1955). This molecular basis is defined by a single plant $\mathrm{R}$ gene for a single pathogen Avr gene, for this reason the name genefor-gene resistance.

In sorghum, a relationship between tan plant and resistance to foliar and panicle diseases was documented (Nicholson et al., 1987; Torres et al., 1992). Nicholson et 
al. (1987) reported the accumulation of phytoalexins (flavonoids) in sorghum in response to pathogen infection. It has been suggested that the type and quantity of anthocyanins (flavonoids) produced in response to pathogen attack in sorghum may vary (Klein et al., 2001). There may be common biosynthetic pathway for the production of the type of flavonoids required for plant colour and for those involved in hypersensitivity. Host plant resistance is specific to certain isolates of a pathogen and less durable and complex than NHR (Gill et al., 2015). Plants produce different types of secondary metabolites with distinct forms and these metabolites confer resistance to pathogens as chemical barriers (Dixon, 2001).

\section{Management Options}

There are several controlling strategies have been recommended for sorghum anthracnose. Cultural practices including altering planting dates, removal of crop residues and alternate hosts (wild sorghum), weed management, planting disease free seeds and crop rotation can serve as important options in preventing sorghum from anthracnose infestation. Management of anthracnose using proper field sanitation as a cultural control measure remains highly sustainable (Marley, et al., 2004) Seed treatment (Akpa et al., 1992) and use of foliar sprays have also been found to be effective in controlling anthracnose but use of fungicide chemicals is generally not economical and sustainable. (Marley, 1996; 1997). Host-plant resistance is generally regarded as the most sustainable, environmental friendly, effective and ideal control strategy (Rosenow and Frederiksen, 1982).

\section{Sorghum Breeding for Anthracnose Resistance}

Breeding for anthracnose resistance appears simple and can be successfully managed using resistant varieties. On the other hand, due to the pathogen population is highly variable and the numerous physiological races which reduces the longevity of resistant sources. Therefore, identification of durable and new resistance requires the screening of sorghum genotypes against multiple races of the pathogen at multiple location (Marley et al., 2001; Mathur et al., 2002; Marley et al., 2005; Valério et al., 2005; Acquaah, 2012; Li et al., 2013). An adequate knowledge of the genetic diversity in anthracnose-resistant germplasm is necessary to use the diversity effectively in sorghum breeding programs (Cuevas et al., 2018).

In addition to identification, the resistance must be characterized for inheritance and reaction across multiple environments before they can be effectively used (Mehta et al., 2005). LeBeau \& Coleman (1950) reported the fact that the leaf and stalk rot stages of anthracnose resistance is under independent genetic control. Costa et al. (2011) observed sorghum anthracnose resistance is controlled by vertical genes with two alleles to specific races of $\mathrm{C}$. sublineolum.

There were also variations in the dominance or recessive in types of gene action to resistance in the lineages used. The Anthracnose resistance in sorghum is controlled by recessive genes (LeBeau and Coleman, 1950; Boora et al., 1998; Singh et al., 2006). In other studies, the inheritance of resistance was reported to be determined by a larger number of genes with an additive effect (Tenkouano and Miller, 1993; Murty and Thomas, 1989). Erpelding and Prom, (2004) and Mehta et al. (2005) reported that resistance is controlled by a single locus with dominant or recessive gene action. Sources of dilatory resistance, inherited as a polygenic trait have also been identified (Casela et al., 1993). Mehta et al. (2005) and Cuevas et al (2014) reported that the resistance is controlled by a single dominant and mapped a dominant gene $(\mathrm{Cg} 1)$ on chromosome 5 at different loci. Thus, this indicates that anthracnose resistance is governed by dominant single or few genes (monogenic) and can be by many minor contributing recessive genes with an additive effect.

Researchers suggested that Ethiopian sorghum germplasm could be an important source of anthracnose resistance (Doggett, 1991; Erpelding, 2010). Ethiopia serves as the global reservoir for sources of favorable genes of various crops to which it is the Vavilovian center of origin and diversity including sorghum [Sorghum bicolor (L.) Moench]. Farmers grow mixed sorghum landraces of diverse forms in their fields for various local purposes. The Ethiopian sorghum germplasm has been highly contributing to the global agriculture (Singh and Axtell, 1973). Besides, some superior varieties of Ethiopian origin were released in India, Eritrea, Burkina Faso, Zambia, Burundi and Tanzania (Reddy et al., 2006) and genetic characterization for anthracnose resistance of the Ethiopian germplasm were investigated by various researchers using different molecular markers (Cuevas et al., 2019; Chala et al., 2011).

\section{Progress and Prospects of Anthracnose Resistance Breeding in Sorghum}

Sorghum research conducted over the last several years has generated interests in the stress-tolerant breeding programme (Rooney et al., 2007). But, most plant pathogens have the ability to undergo genetic recombination causing the emergence of pathogenic lineages and/or the formation of novel genetic diversity, which may lead to the genesis of new pathogens with increased pathogenicity resulting in breakdown of resistance crop varieties and pose a serious and continuing threat in crop production, makes the breeding activities more complex (Brasier, 2001; Wingfield et al., 2001; Giraud et al., 2010; Fisher et al., 2012). Plant pathogenic fungi show a variety of interactions with their host plants, changing their relationship at different stages of their life cycle depending on the physiological maturity and resistance of the host, the environment and associated virulence genes of the pathogen (Stergiopoulos and deWit, 2009; Newton et al., 2010; Delaye et al., 2013).

Employment of genetic resistance is generally regarded as the most effective disease control strategy to control anthracnose (Harris and Fisher, 1973; Rosenow and Frederiksen, 1982; Frederiksen, 1984; Rezende et al., 2004). Different sources of anthracnose resistance have been identified in sorghum and mapped by several groups of researchers. In sorghum anthracnose disease, the occurrence of different pathotypes and levels of pathogenicity within the pathogen population makes very critical in the identification of additional sources of resistance (Prom et al., 2012). Sharma et al. (2012) 
observed in sorghum tremendous genetic variation for reaction to anthracnose pathogen has been demonstrated in the mini-core collection. Upadhyaya et al. (2013) reported the evidence that anthracnose resistance is mostly influenced by genes rather than environmental conditions and resistance to anthracnose is mostly under monogenic control (Erpelding and Wang, 2007; Costa et al., 2011).

In addition to resistance screening under field and green house level based on phenotypic reaction, identification of gene(s)/genomic area using different molecular makers under molecular laboratories was conducted by several researchers for different sorghum population and races. Mohan et al. (2010) identified four anthracnose resistance loci and three of those are on chromosome 6. Biruma et al. (2012) Identified seven candidate genes, evaluated using virus-induced gene silencing (VIGS), leading to the identification of two R-genes encoding proteins with NBSLRR domains, Cs1 A and Cs2A, as the primary sources of anthracnose resistance.

The report by Klein et al. (2001) from mapping a quantitative trait locus (QTL) for anthracnose resistance revealed three QTLs on chromosome 6 and one QTL on chromosome 4. The QTL on chromosome 6 overlapped with QTL for resistance against other diseases also observed during that study. Upadhyaya et al., (2013) conducted association study for anthracnose resistance used the sorghum mini-core collection. The study of association analysis using SNPs marker and identified eight loci linked to anthracnose resistance; four on chromosome 1, two on chromosome 6 , one on chromosome 8 , and one on chromosome 10 . The loci on chromosome 6 colocalized with the resistance loci discovered by (Mohan et al., 2010). So, the approach integrates QTL analysis with variety development by simultaneously identifying QTLs and transferring favorable QTLs from unadapted source into cultivated varieties.

Now a day advances in molecular plant breeding and genomics play a key role in grass-to-peroxide resistance breeding and various molecular marker assisted activities have been successfully conducted. SSRs and SNPs have become the most popular in identifying targeted traits and genetic variation in natural populations differing robustness and consistency of the results obtained with these two markers (Guichoux et al., 2011; Martin et al., 2017). In high-throughput DNA sequencing, computer software and bioinformatics have made the use of SNPs more popular. (Heaton et al., 2002) and although in terms of genetic information a bi-allelic marker may be considered as a step backwards, SNPs have some promising advantages, including greater abundance (Heaton et al., 2005), simpler nomenclature and suitability to automated analysis and data interpretation (LindbladToh et al., 2000). Also, SNPs have been successfully used in the discovery of quantitative trait loci (QTL) and the association of genes with specific productive traits (Wollstein et al., 2007).

Economically important traits in all crops were improved through different breeding approaches. But, utilization of a novel alien gene for crop improvement is the major restriction in conventional breeding. Transgenic approach is a powerful tool to utilize successfully. Now a day, transgenic sorghum lines have been generated for resistance to biotic and abiotic stresses such as anthracnose (Ayoo et al., 2011); resistance to stem borer (Visarada et al., 2014); resistance to drought tolerance (Guo et al., 2005); Resistance to saline soil (Maheswari et al., 2010). Utilizing transgenic technology for improving yield and quality of sorghum transgenes are successfully used for disease and insect pest resistance and abiotic stress tolerance. Transgenic approach is a powerful method that utilizing in developing anthracnose resistance cultivars in sorghum. The anthracnose resistance sorghum transgenics with two antifungal genes, chitinase (harchit) and chitosanase (harcho) isolated from Trichoderma harzianum through the particle bombardment method in the KAT 412 genotype (wild type) and reported that seedlings from a transgenic line, (KOSA-1), were found to be significantly more tolerant to anthracnose than the parent KAT 412 (Kosambo-Ayoo et al., 2011). Compared to other cereals Sorghum considered to less responsive vitro culture manipulation due lack of continuous regeneration and phenolic compound production (Saikishore et al., 2005).

Transgene expression efficiency is dependent on the promoter that regulating it, and also depends on the plant species that is being examined (Able et al., 2001). Currently, ubil is considered to be the most efficient promoter for transgene expression in sorghum and is used predominantly in sorghum studies (Raghuwanshi and Birch, 2010; (Liu and Godwin, 2012).

\section{Conclusion}

Sorghum is the most important cereal crop supporting the lives of millions of people around the globe. The crop has versatile and diverse genetic resource to be exploited further by breeders to develop resistance to any stresses. In spite of the diverse genetic resources, the average yield is still far below the potential. This is due to different biotic and abiotic factors. Anthracnose caused by C. sublineolum is the major devastating disease among biotic stresses. Anthracnose of sorghum causes economic losses to sorghum worldwide. Research has identified various sorghum germplasm with moderate to high resistance to the disease. The use of resistant varieties is the most efficient and economical strategy for controlling this pathogen. However, the pathogen exhibits a very larger variability that allows its rapid adaptation to the genetic resistance found in commercial varieties of sorghum. Thus, development and availability of new resistance varieties is very critical and needs breeders too much effort for development of durable resistant improved varieties. The recent advancements in molecular works help molecular marker assisted breeding can speed up the breeding progress, successfully discovery of genes/QTL associated with the resistance. So, using high through put molecular markers like SNPs facilitates the easiest way for gene pyramiding from different individual genotypes to a single variety to develop durable resistance varieties.

\section{Acknowledgments}

The author wishes to thank the reviewers for constructive comments to improve the quality of this manuscript. All authors of the references cited in this paper were duly acknowledged. 


\section{Conflicts of Interest}

The author declared that no conflict of interest.

\section{References}

Able J, Rathus C, Godwin I. 2001. The investigation of optimal bombardment parameters for transient and stable transgene expression in sorghum. In Vitro Cell. Dev. Biol. Plant, 37: $341 \mathrm{e} 348$

Acquaah G. 2012. Principle of Plant Genetics and Breeding 2nd Edition. John Wiley \& Sons, Ltd.

Adebo O. Njobeh P, Mulaba-Bafubiandi A, Adebiyi J, Desobgo SC, Kayitesi E. 2018. Optimization of fermentation conditions for ting production using response surface methodology. J. Food Process Preservation, 42(1): e13381. https://doi.org/doi: 10.1111/jfpp.13381

Akpa A, Gana S, Alabi O. 1992. Foliarfungicidal spray for the control of some common foliar diseases of sorghum. Nigerian J. Ournal of Plant Protection, 14: 92-96.

Alemayehu C, Brurberg M, Tronsmo A. 2010. Incidence and severity of sorghum anthracnose in Ethiopia. Plant Pathology Journal, 9: 23-30.

Ali MEK, Warren HL, Latin RX. 1987. Relationship between anthracnose leaf blight and losses in grain yield of sorghum. Plant Disease, 71: 803-806.

Almodares A, Hadi MR, Ahmadpour H. 2008. Sorghum stem yield and soluble carbohydrates under different salinity levels. African Journal of Biotechnology, 7: 4051-4055.

Anonymous. 2006. Agricultural Statistics of Pakistan.

Ayoo L, Bader M, Loerz H, Becker D. 2011. Transgenic sorghum (Sorghum bicolor L. Moench) developed by transformation with chitinase and chitosanase genes from Trichoderma harzianum expresses tolerance to anthracnose. Afr. J. Biotechnol, 10: 3659- 3670.

Batey I. 2017. The diversity of uses for cereal grains. In C. CWrigley, I. Batey, \& D. Miskelly (Eds.), Cereal Grains (pp. 41-53). Elsevier: Amsterdam, The Netherlands.

Berenji J, Dahlberg J. 2004. Perspectives of sorghum in Europe. Journal of Agron Crop Sciences, 190(5): 332-338.

Bhagavatula S, Rao P, Basavaraj G, Nagaraj N. 2013. Sorghum and Millet Economies in Asia-Facts, Trends and Outlook.

Bian M, Zhou M, Sun D, Li C. 2013. Molecular approaches unravel the mechanism of acid soil tolerance in plants. Crop J, 1(2): 91-104. https://doi.org/10.1016/j.cj.2013.08.002

Bogdanove A. 2002. Protein interactions in pathogen recognition by plants. Plant Molecular Biology, 50, 981-989.

Boora K, Frederiksen R, Magil C. 1998. DVA-based markers for a recessive gene conferring anthracnose resistance in sorghum. Crop Science, 38, 1708-1709.

Bourget R, Chaumont L, Sapoukhina N. 2013. Timing of pathogen adaptation to a multicomponent treatment. PLoS One, 8, 1-11.

Boyer J. 1982. Plant Productivity And Environment. Science, 218, 443-448.

Brasier CM. 2001. Brasier, Rapid Evolution of Introduced Plant Pathogens via Interspecific Hybridization: Hybridization is leading to rapid evolution of Dutch elm disease and other fungal plant pathogens. BioScience, 51(2): 123-133. https://doi.org/10.1641/0006-

3568(2001)051[0123:REOIPP]2.0.CO;2

Burrell A, Sharma Patil N, Collins S, Anderson W, Rooney W, Klein P. 2015. Sequencing of an anthracnose-resistant sorghum genotype and mapping of a major QTL reveal strong candidate genes for anthracnose resistance. Crop Science, 55(2): 790-799.

Casela C, Frederiksen R. 1993. Survival of Colletotrichum graminicola sclerotia in sorghum stalk residues. Plant Disease, 77, 825-827.
Casela C, Ferreira A, Rederiksen R. 1993. Evidence for dilatory resistance to anthracnose in sorghum. Plant Disease, 77: 908911.

Chala A, Alemu T, Prom LK, Tronsmo, AM. 2010. Effect of host genotypes and weather variables on the severity and temporal dynamics of sorghum anthracnose in Ethiopia. Plant Pathology Journal, 9: 39-46.

Chala A, Tronsmo A, Brurberg M. 2011. Genetic differentiation and gene flow in Colletotrichum sublineolum in Ethiopia, the center of origin and diversity of sorghum, as revealed by AFLP analysis. Plant Pathology, 60: 474-482.

Challinor A, Watson J, Lobell D, Howden S, Smith D, Chhetri, N. A. 2014. meta-analysis of crop yield under climate change and adaptation. Nat. Clim. Chang., 4: 287-291.

Clayton WD, Renovoize SA. 1986. Genera Graminum: Grasses of the World, Kew Bulletin Additional Series Royal Botanic Gardens, 13, 389.

Cole CT. 2003. Genetic variation in rare and common plants. Annual Review of Ecology, Evolution, and Systematics, 34, 213-227. https://doi.org/doi: 10.1146/annurev.ecolsys.34.030102.151717

Costa R, Zambolim, Cota L, da Silva D, Rodrigues J, Tardin F, Casela C. 2011. Genetic control of sorghum resistance to leaf anthracnose. Plant Pathol Ogy, 60, 1162-1168.

Costa R, Zambolim L, Cota L, Silva D, Parreira D, Lanza F, Souza A 2014. Pathotypes of Colletotrichum sublineolum in response to sorghum populations with different levels of genetic diversity in Sete Lagoas-MG. Journal of Phytopathology, 163(7-8): 543-553. https://doi.org/https:// doi.org/10.1111/jph.12352

Crouch J, Beirn L. 2009. Anthracnose of cereals and grasses. Fungal Divers, 39:19.

Cuevas EH, Prom KL, Elizabeth AC, Joseph EK, Xinzhi N. 2018. Genome-Wide Association Mapping of Anthracnose (Colletotrichum sublineolum) Resistance in the U.S. Sorghum Association Panel. The Plant Genome, 11(2): 1-13. https://doi.org/10.3835/plantgenome2017.11.0099

Dahlberg JA Wasylikowa K. 1996. Image and statistical analyses of early sorghum remains (8000 B. P.) from the Nabta Playa archaeological site in the Western Desert, southern Egypt. Vegetation History and Archaeobotany, 5, 293-299.

Dahlberg J, Berenji J, Sikora V, Latković D. 2011. Assessing sorghum [Sorghum bicolor (L.) Moench] germplasm for new traits: Food, fuels and unique uses. Maydica, 56: 85-92.

Deb U, Bantilan M, Hash C, Ndjeunga J. 2004. Adoption of Improved Sorghum Cultivars. In Sorghum Genetic Enhancement.

Delaye L, Garcia-Guzman G, Heil, M. 2013. Endophytes versus biotrophic and necrotrophic pathogenseare fungal life styles evolutionarily stable traits? Fungal Diversity, 60,,: 125-135.

Dixon R. 2001. Natural products and plant disease resistance. Nature, 411, 843-847.

Doggett H. 1991. Sorghum history in relation to Ethiopia. In J. M.M. Engels \& J. G. Hawkes (Eds.): Plant Genetic Resources of Ethiopia (pp. 140-159). Cambridge University Press. https://doi.org/https://doi.org/10.1017/CBO9780511551543.011

Doggett H. 1988. Sorghum., 2nd Edition. Longman Scientific and Technical, Burnt Mill, Harlow, Essex, Ingland. John Wiley \& Sons.

Dyer GA, Lopez-Feldman A, Yunez-Naude A, Taylo, JE. 2014. Genetic erosion in maize's center of origin. PNAS. Genetic Erosion in Maize's Center of Origin, 111, 14094-14099.

Eberhart S, Bramel Cox P, Prasada R. 1997. Preserving Genetic resources. International Confference on Genetic Improvement of Sorghum and Pearl Millet 22-27 Sep 1996. Holidy Inn. Plaza, Lubbock Taxas, Loncoln, Nebrasks,USA, INTSORMIL/ICRISAT, 25-41.

Ejeta G, Grenier C. 2005. Sorghum and its weedy hybrids. In J. Gressel (Ed.): Crop Ferality and Volunteerism (pp. 123-135). CRC Press, Boca Raton, Florida, USA. 
Erpelding J. 2010. Anthracnose Resistance in Sorghum Breeding Lines Developed from Ethiopian Germplasm. Plant Health Progress, 11(1): 1-12. https://doi.org/10.1094/php-2010-1123-02-rs

Erpelding J, Wang M. 2007. Response to anthracnose infection for a random selection of sorghum germplasm. Plant Pathology, 6: 127-133.

Erpelding JE, Prom LK. 2004. Evaluation of Malian sorghum germplasm for resistance against anthracnose. Plant Pathology Journal, 3: 65-71.

Esele JP. 1995. Foliar and head diseases of sorghum. African Crop Science Journal, 3(2): 185-189.

FAO. 2000. Food and Agriculture Organisation of the United Nations FAO) 2000 Global network on integrated soil management for sustainable use of salt-affected soils. FAO Land and Plant Nutrition Management Service, Rome, Italy See Http://Www.Fao.Org/Ag/Agl/Agll/Spush.

FAO. 2009. Global agriculture towards 2050.

FAO. 2011. The state of food and agriculture. Women in Agriculture. Closing the Gender gap for Development. In FAO.

Fisher M, Henk D, Briggs C, Brownstein J, Madoff L, McCraw S, Gurr S. 2012. Emerging fungal threats to animal, plant and ecosystem health. Nature, 484, 186-194.

Flor H. 1955. Host-parasite interaction in flax rust: its genetics and other implications. Phytopathology, 45, 680-685.

Flor H. 1971. Current status of the gene-for-gene concept. Annu Rev Phytopathol, 9, 275-296. https://doi.org/10.1146/ annurev.py.09.090171.001423

Foulkes M, Slafer GA, Davies WJ, Berry PM, Bradley RS, Martre P, Calderini DF, Griffiths S, Reynolds M.P. 2011. Raising yield potential of wheat III. Optimizing partitioning to grain while maintaining lodging resistance. Journal of Experimental Botany, 62: 469-486.

Frederiksen R. 1984. Anthracnose stalk rot. Sorghum Root and Stalk Rots, a Critical Review. Proceedings of the Consultative Group Discussion on Research Needs and Strategies for Control of Sorghum Root and Stalk Rot Diseases, 27 November-2 December 1983. ICRISAT, Bellagio, Italy, 37-40.

Garber E. 1950. Cytotaxonomic studies in the genus Sorghum. Botany, 23, 283-361.

Gezahegn G, Habte N, Amare S, Moges M, Amare N, Dagnachew L, Kebede D, Alemnesh B, Adane G, Adedayo A, Alemu T, Getachew A, Taddese T, Firew M, Ketema B, Tesfaye T, Gebisa E, Mengist, T. 2019. Identification of sorghum grain mold resistance loci through genome wide association mapping. Journal of Cereal Science, 85. https://doi.org/10.1016/j.jcs.2018.12.016

Gill U, Lee S, Mysore K. 2015. Host versus nonhost resistance: Distinct wars with similar arsenals. Phytopathology, 105, 580-587.

Giraud T, Gladieux P, Gavrilets S. 2010. Linking the emergence of fungal plant diseases with ecological speciation. Trends in Ecology \& Evolution, 25, 387-395.

Glaszmann J, Kilian B, Upadhyaya HD, Varshney K. 2010. Accessing genetic diversity for crop improvement. Current Opinion in Plant Biology, 13, 167-173.

Guichoux E, Lagache L, Wagne S, Chaumeil P, Léger P, Lepais O, Lepoittevin C, Malausa T, Revardel E, Salin F, Petit R. 2011. Current trends in microsatellite genotyping. Molecular Ecology Rsesource, 11(4): 591-611. https://doi.org/https:// doi.org/10.1111/j.1755-0998.2011.03014.x

Guo Z, Jayaraj J, Muthukrishnan S, Claflin L, Liang G. 2005. Efficient genetic transformation of sorghum using a visual screening marker. Genome, 48, 321e333.le.

Hafsi C, Romero-Puertas M, Gupta D, Rio LA, Sandalio L, Abdelly C. 2010. Moderate salinity enhances the antioxidative response in the halophyte Hordeummaritimum L. under potassium deficiency. Environmental and Experimental Botany, 69(2): 129-136. https://doi.org/https://doi.org/10.1016/j.envexpbot.2010.04.008.
Hancock JD. 2000. Value of Sorghum and Sorghum Co-products in Diets for Livestock. Sorghum: Origin, History, Technology, and Production,John Wiley \& Sons, New York, 731-749.

Harlan J, Dewet JMJ. 1972. A simplified classification of cultivated sorghum. Crop Science, 12, 172-176. https://doi.org/10.2135/cropsci1972.0011183X0012 00020005x

Harris H, Fisher, C. 1973. Yield of grain sorghum in relation to anthracnose expression at different developmental stages of host. Proceedings of the Association of Southern Agricultural Workers, 44-46.

Harris HB, Johnson B, Dobson J, Luttrell E. 1964. Evaluation of anthracnose on grain sorghum. Crop Science, 5(4): 460-462.

Heaton M, Harha y G, Bennett G, Stone R, Grosse W, Casas E, Keele J, Smith T, Chitko-McKown C, Laegreid W. 2002. Selection and use of SNP markers for animal identification and paternity analysis in U.S. beef cattle. Mamm Genome, 13, 272-281.

Heaton M, Keen J, Clawson M, Harhay G, Bauer N, Schultz C, Green B, Durso L, Chitko-McKown C, Laegreid W. 2005. Use of bovine single nucleotide polymorphism markers to verify sample tracking in beef processing. Journal of Animal Veterinary Medicine Association, 226, 1311-1314.

Hugo EC, Louis KP, Clara MCB. 2019. Genome-Wide Association Mapping of Anthracnose (Colletotrichum sublineolum) Resistance in NPGS Ethiopian Sorghum Germplasm. G3. Genes/Genomes/Genetics, 9(September): 2879-2885. https://doi.org/10.1534/g3.119.400350

Hulluka M, Esele J. 1992. Sorghum diseases in Eastern Africa. In de M. WJA, F. RA, \& B. GD (Eds.): A second world reviews of Sorghum and millet diseases (pp. 502 324: 21-24).

Hussain F, Abid M. 2011. Pests and diseases of chili crop in Pakistan: A review. International Journal of Biology and Biotechnology, 8, 325-332.

IPGRI. 1983. Diversity for development. International Plant Genetic Resources Institute. Rome, Italy.

Iqbal A, Sadia B, Khan A, Awan F, Kainth R, Sadaqat H. 2010. Biodiversity in the Sorghum (Sorghum bicolor L. Moench) Germplasm of Pakistan. Genetic Molecular Research, 9, 756-764.

Kebede Y. 1991. The role of Ethiopian sorghum germplasm resources in the national breeding programme. Plant Genetetic Resource, 315-322.

Keen N. 1990. Gene-for-gene complementarity in plant-pathogen interactions. Annual Review of Genetetics, 24: 447-463.

Kelly J, Allejo V. 2004. A comprehensive review of the major genes conditioning resistance to anthracnose in common bean. Hort Science, 39, 1196-1207.

Klein R, Rodriguez-Herrera R, Schlueter J, Klein P, Yu Z, Rooney W. 2001. Identification of genomic regions that affect grain-mould incidence and other traits of agronomic importance in sorghum. Theory of Appliesd Genetetics, 102, 307-319.

Klein RR, Rodriguez-Herrera R, Schlueter J, Klein P, Yu Z, Rooney W. 2001. Identification of genomic regions that affect grain mould incidence and other traits of agronomic importance in sorghum. Theory of Applied Genetic, 102, 307-319.

Kochian L. 1995. Cellular mechanisms of aluminum toxicity and resistance in plants. Annual Review of Plant Biology, 46, 237-260.

Kosambo-Ayoo L, Bader M, Loerz H, Becker, D. 2011. Transgenic sorghum (Sorghum bicolor L. Moench) developed by transformation with chitinase and chitosanase genes from Trichoderma harzianum expresses tolerance to anthracnose. Afr. J. Biotechnol, 10, 3659e3670.

LeBeau F, and Coleman, O. 1950. The inheritance of resistance in sorghum to leaf anthracnose. Agronomy Journal, 42: 33-4.

Li L, Zhu F, Liu H, Chu A, Lo, C. 2013. Isolation and expression analysis of defense-related genes in sorghum Colletotrichum sublineolum interaction. Physiological and Molecular Plant Pathology, 84, 123-130. https://doi.org/https ://doi.org/ 10.1016/j.pmpp.2013.08.005 
Lin Z, Li X, Shannon LM, Yeh CT, Wang ML, Bai G, Peng Z, LI J, Trick H. N, Clemente T, Doebley J. F, Schnable P, Tuinstra M.R, Tesso, T. T, White F, Yu J. 2012. Parallel domestication of the Shattering1 genes in cereals. Nature Genetics, 44, 720-724.

Lindblad-Toh K, Winchester E, Daly MJ, Wang DG, Hirschhorn JN, Laviolette JP, Ardlie K, Reich DE, Robinson E, Sklar P, Shah N, Thomas D, Fan JB, Gingeras T, Warrington J, Patil N, Hudson TJ, Lander ES. 2000. Large-scale discovery and genotyping of single-nucleotide polymorphisms in the mouse. Nat Genet. 2000 Apr;24(4): 381-6. doi: 10.1038/74215. PMID: 10742102.

Liu G, Godwin I. 2012. Highly efficient sorghum transformation. Plant Cell Rep., 31, 999e1007.

Lobell D, Burke M, Tebaldi C, Mastrandrea M, Falcon W, Naylor R. 2008. Prioritizing climate change adaptation needs for food security in 2030. Science, 319: 607-610. https://doi.org/10.1126/science.1152339

Rivera-Buros LA, Volenec JJ, Ejeta G. 2019. Biomass and Bioenergy Potential of Brown Midrib Sweet Sorghum Germplasm. Frontiers Plant Sciences, 1-12. https://doi.org/10.3389/fpls.2019.01142

Mace E.S, Tai S, Gilding E.K, Peter Y.L, Bian P.L and et al. 2013. Whole-genome sequencing reveals untapped genetic potential in Africa's indigenous cereal crop Sorghum. Nature Communications 4. https://doi.org/10.1038/ncomms3320

Maheswari M, Varalaxmi Y.V, AYadav S.K, Sharmila P, Venkateswarlu B, Vanaja M, PSaradhi P. 2010. Metabolic engineeringusing $\mathrm{mtlD}$ geneenhances tolerancetowater deficitandsalinity in sorghum. Biol Plant, 54, 647-652.

Mann J, Kimber C, Miller F. 1983. The origin and early cultivation of sorghums in Africa. Texas Agricultural Experiment Station Bulletin, 1454.

Marley P, Diourte M, Neya A, Rattunde F. 2005. Sorghum anthracnose and sustainable management strategies in West and Central Africa. Journal of Sustainable Agriculture, 21(1): 43-56.

Marley P.S Thakur R.P, Ajayi O. 2001. Variation among foliar isolates of Colletotrichum sublineolum of sorghum in Nigeria. Field Crops Research, 69, 133-142.

Marley P.S. 1996. Sorghum Pathology. Cereals Research Program Report to the Annual Cropping Scheme Meeting. Institute for Agricultural Research, Ahmadu Bello University, Samaru, Zaria, Nigeria.

Marley P.S. 1997. Sorghum Pathology. Cereals Research Program Report to The1997Annual Cropping Scheme Meeting. Institute for Agricultural Research, Ahmadu Bello University, Samaru, Zaria, Nigeria.

Marley Paul S. 2004. Sorghum Anthracnose and Sustainable Management Strategies in West and Sorghum Anthracnose and Sustainable Management Strategies in West and Central Africa. Journal of Sustainable Agriculture, 25(1): 43-56. https://doi.org/10.1300/J064v25n01

Martin C, Christian R, Marianne L, Marie R, Felix G, Kentaro K, Rolf H. Alex W. 2017. Estimating genomic diversity and population differentiation-an empirical comparison of microsatellite and SNP variation in Arabidopsis halleri. BMS Genomics, 18, 69. https://doi.org/DOI 10.1186/s12864-016-3459-7

Mathur K, Thakur R.P, Neya A, Marley S.P, Casela C.R., Rosewich L. U. 2002. Sorghum and Millets Pathology. In J. Leslie (Ed.): Sorghum anthracnose-problem and management strategies, Iowa State University Press, Ames, Iowa, USA. (Vol. 2000, pp. 211-220).

Mehmood S, Bashir A, Ahmad A, Akram Z, Jabeen N, Gulfraz M. 2008. Molecular characterization of regional sorghum bicolor varieties from Pakistan. Pakistan Journal of Botany, 40(5): 2015-2021.

Mehta P, Wiltse C, Rooney W, Collins S, Frederiksen R, Hess D, Chisi M, TeBeest D. 2005. Classification and inheritance of genetic resistance to anthracnose in sorghum. Field Crop Research, 93(1): 1-9.
Mejia D, Lewis B. 1999. Food Security Department. Sorghum: Post-harvest Operations. In INPhO-Post-Harvest Compendium;

Miao Z, Han Z, Zhang T, Chen S, Ma C. 2017. A systems approach to a spatio-temporal understanding of the drought stress response in maize. In Scientific Reports (Vol. 7).

Mishra A. 1957. Outbreaks and new records. FAO Plant Protection Bulletin, 5: 145-146.

Mohan SM, Madhusudhana R, Mathur K, Chakravarthi DVN, Sanjay RR. Nagaraja R, Satish K, Srinivas GN, Sarada M, Seetharama N. 2010. Identification of quantitative trait loci associated with resistance to foliar diseases in sorghum [ Sorghum bicolor (L.) Moench] Identification of quantitative trait loci associated with resistance to foliar diseases in sorghum [ Sorghum bicolor (L. Euphytica, 176, 199-211. https://doi.org/10.1007/s10681-010-0224-x

Mullet J, Morishige D, Mccormick R, Truong S, Hilley J, Mckinley B, Anderson R, Olson S.N, Rooney W. 2014. Energy Sorghuma genetic model for the design of $\mathrm{C} 4$ grass bioenergy crops. 65(13): 3479-3489. https://doi.org/ $10.1093 /$ jxb/eru229

Munns R. 2005. Genes and salt tolerance: bringing them together. New Phytologist, 167, 645-663.

Murphy J, Wong F, Tredway L, Crouch J, Inguagiato J, Clarke B, Hsiang T, Rossi F. 2008. Best management practices for turf grass anthracnose disease. Golf Course Management, 76, 93104.

Murty D, Thomas M. 1989. Preliminary studies on the inheritance of resistance to leaf anthracnose and gray leaf spot disease of sorghum (Sorghum bicolor (L.) Moench). Sorghum Newsletter, 31:83.

Newton A, Fitt B, Atkins S, Walters D, Daniell T. 2010. Pathogenesis, parasitism and mutualismin the trophic space of microbe-plant interactions. Rends Microbio, 18, 365e 373.

Ng'uni D, Geleta M, Bryngelsson T. 2011. Genetic diversity in sorghum (Sorghum bicolor (L.) Moench) accessions of Zambia as revealed by simple sequence repeats (SSR). Hreditas, 148, 52-62.

Ngugi H, King S, Abayo G, Reddy Y. 2002. Prevalence, and Severity of sorghum diseases in Western Kenya. Deasese, 86, 65-70.

Nicholson R, Kollipara S, Vincent J, Lyons P, Cadena-Gomez, G. 1987. Phytoalexin synthesis by the sorghum mesocotyl in response to infection by pathogenic and nonpathogenic fungi. Proceeding of Natlional Academy Science USA, 84, 55205524.

OECD. 2016. Organization for Economic Co-operation and Development: Consensus Document on the Biology of Sorghum (Sorghum bicolor L. Moench). Series on Harmonisation of Regulatory Oversight in Biotechnology No. 62.

Ort D. R, Merchant SS, Alric J, Barkan A, Blankenship RE, Bock R, Croce R, Hanson MR, Hibberd JM, Long SP, Moore TA, Moroney J, Niyogi KK, Parry MAJ, Peralta-Yahya PP Princ RC, Redding KE, Spalding MH and et al. 2015. Redesigning photosynthesis to sustainably meet global food and bioenergy demand. Proceedings of the National Academy of Sciences of the United States of America, 112 (28) :8529-8536.

Panaccione D, Vaillancourt L, Hanau R. 1989. Conidial dimorphism in Colletotrichum graminicola. Mycologia, 81, 876-883.

Parlevliet J. 1989. Identification and evaluation of quantitative resistance. In K. Leonard \& W. Fry (Eds.): Plant disease epidemiology, Genetics, Resistance and Management, Vol. 2 (pp. 215-248.pp). McGraw - Hill Publishing Company, New York.

Pastor A, Palazzo A, Havlik P, Biemans H, Wada Y, Obersteiner M, Kabat P. L. F. 2019. The global nexus of food-trade-water sustaining environmental flows by 2050 . Nature Sustainability, 2, 499-507. https://doi.org/https://doi.org/10.1038/s41893-019$0287-1$ 
Paterson A, Bowers J, Bruggmann R, Dubchak I, Grimwood J, $\mathrm{Al}$, E. 2009. The Sorghum bicolor genome and the diversification of grasses. Nature, 457: 551.

Patil N, Klein R, Williams C, Collins S, Knoll J, AM B, Anderson W, Rooney W, Klein P. 2017. Quantitative trait loci associated with anthracnose resistance in sorghum. Crop Science, 57(2): 877-890.

Perumal R, Menz M, Mehta P. 2009. Molecular mapping of Cg1, a gene for resistance to anthracnose (Colletotrichum sublineolum) in sorghum. Euphytica, 165, 597-606.

Prasad PV, Staggenborg S, Ristic Z. 2008. Impacts of drought and/or heat stress on physiological, developmental, growth and yield processes of crop plants. In L. Ahuja, L. Ma, \& S. Saseendran (Eds.): Responses of Crops to LimitedWater: Understanding and Modeling Water Stress Effects on Plant Growth Processes: Advances in Agricultural Modeling Series 1 (pp. 301-355). ASA-CSSA: Madison, WI, USA.

Prom LK, Erpelding J, Perumal R, Isakeit T, Cuevas H. 2012. Response of Sorghum Accessions from Four African Countries against Colletotrichum sublineolum, Causal Agent of Sorghum Anthracnose. American Journal of Plant Sciences, 3, 125-129. https://doi.org/10.4236/ajps.2012.31014

Raghuwanshi A, Birch R. 2010. Genetic transformation of sweet sorghum. Plant Cell Rep, 29(9): 997e1005.

Reddy B, Ramesh S, Reddy P, Kumar A. 2009. Genetic enhancement for drought tolerance in sorghum. Plant Breed Rev, 31, 189-222.

Reddy BVSR, Reddy P, Ramaiah B, Salimath P, Kachapur R. 2005. Sweet Sorghum-A Potential Alternate Raw Material for Bio-ethanol and Bio-energy. International Sorghum Millets Newslett, 46, 79-86.

Reddy VG, Upadhyaya HD, Gowda CLL. 2006. Their Sharing and Impacts Initial Attempts at Sorghum Germplasm Collection at ICRISAT. Current Status of Sorghum Genetic Resources at ICRISAT, 47, 9-13.

Rezende VF, Vencovsky R, Cárdenas FEN, Silva H, Bearzoti E, and et.al. 2004. Mixed inheritance model for resistance to anthracnose leaf blight in maize. Crop Breeding and Applied Biotechnology, 4, 115-122.

Rohila JS, Jain RK, Wu R. 2002. Genetic improvement of Basmati rice for salt and drought tolerance by regulated expression of a barley Hva1 cDNA. Plant Sci., 163, 525-532. https://doi.org/10.1016/S0168-9452(02)00155-3)

Rooney W, Collins S, Klein R, Mehta P, Frederiksen RodriguezHerrera RR. 2008. Breeding sorghum for resistance to anthracnose, grain mold, downy mildew, and head smuts. Sorghum and Millets Diseases., 273-279.

Rosenow D, Frederiksen, R. 1982. Breeding for disease resistance in sorghum. In L. House, L. Mughogho, \& J. M. Peacock (Eds.): Sorghum in the Eighties Proceedings of the International Symposium on Sorghum (pp. 2: 447-455). Patancheru, AP, India: ICRISAT

Rosenow DT, Dahlberg J. 2000. Collection, Conservation and Utilization of Sorghum. In R. Smith, CW Frederickson (Ed.): In Sorghum origin, history, technology and Production (pp. 309-328). John Wiley and Sons.INC.

Saikishore N, Ramanakumari B, Balakrishna D, Rao SV, Bhat BV, Seetharama N, Visarada KBRS. 2005. Constraints and relevant strategies in genetic transformation of sorghum. In A. Kumar, S. Roy, \& S. K. Sopory (Eds.): Plant biotechnology and its application (pp. 33-40).

Sanwal SK, Singh B, Vikrant S, Anita M. 2015. Multivariate analysis and its implication in breeding of desired plant type in garden pea (Pisum sativum). Indian Journal of Agricultural Sciences, 85(10): 1298-1302.

Shannon MC. 1997. Adaptation of plants to salinity. Advanced Agronomy, 60, 75-120.

Sharma R, Upadhyaya H, Manjunatha S, Rao V, Thakur, R. 2012. Resistance to foliar diseases in a mini-core collection of sorghum germplasm. Plant Disease, 96, 1629-1633.
Singh M, Chaudhary K, Singal H, Magill C, KS, B. 2006 Identification and characterization of RAPD and SCAR markers linked to anthracnose resistance gene in sorghum [Sorghum bicolor (L.) Moench]. Euphytica, 149, 149-87.

Singh R, Axtell J. 1973. High lysine mutant gene (hl) that improves protein quality and biological value of grain sorghum. Crop Science, 13, 535.

Singla J, Krattinger SG. 2016. Biotic Stress Resistance Genes in Wheat. In J. Faubion, H. Corke, \& K. Seetharaman (Eds.): Encyclopedia of Food Grains (pp. 388-392). Oxford: Elsevier Zurich, Switzerland. https://doi.org/http:/10.1016/ B978-0-12-394437-5.00229-1

Smith C, Frederiksen R. 2000. Sorghum: origin, history, technology, and production (Issue 824). John Wiley and Sons.

Stergiopoulos I, DeWit P. 2009. Fungal effector proteins. Annual Review of Phytopathology, 47, 233-263.

Stoop W, Pattanayak W, Matlon P, Root. WR 1982. A strategy to raise productivity of subsistence farming systems in West African semi-arid tropics. In L. House, L. Mughogho, J. Peacock, \& J. Mertin (Eds.): Sorghum in the Eighties (pp. 519-526). ICRISAT, A.P. India.

Sugui J, Leite B, Nicholson R. 1998. Partial characterization of the extracellular matrix released onto hydrophobic surfaces by conidia and germlings of Colletotrichum graminicola. Physiological and Molecular Plant Pathology, 52, 411-425.

Sujay R, Hariprasanna G, Sunil K, Ganapathy KN, Das IK, Ramana O. VDhandapani A, Patil JV. 2014. Changes in Area, Yield Gains, and Yield Stability of Sorghum in Major Sorghum Producing Countries. Crop Sciences Society of America, 54, 1571-1584.

Sukno S, Garci'a V, Shaw B, Thon M. 2008. Root infection and systemic colonization of maize by Colletotrichum graminicola. Applied and Environmental Microbiology, 74, 823-832.

Szabolcs I. 1994. Soils and salinization. In M. Pessarakli (Ed.): In Handbook of plant and crop stress (pp. 3-11). Marcel Dekker, New York

Tenkouano A, Miller, F. 1993. A single locus with multiple alleles as the genetic basis of anthracnose resistance in sorghum. In Sorghum Newsletter (p. 34:45).

Tesso TT, Perumal R, Little CR, Adeyanju A, Radwan GL, Prom LK, Magill CW. 2012. Sorghum pathology and biotechnologya fungal disease perspective: part II. Anthracnose, stalk rot, and downy mildew. Europian Journal of Plant Sci Ences and Biotechnology, 6, 33-44.

Thakur R, Mathur K. 2000. Anthracnose. in: Compendium of Sorghum Diseases. In R. A. Frederiksen, E. G. N. Odvody, \& M, St. Paul (Eds.): American Phytopathological Society (pp. 10-12).

Thakur RP, Reddy, B, Mathur K. 2007. Screening Techniques for Sorghum Diseases. Information: Bulletin No. 76. ICRISA, Patancheru, Andhra Pradesh, India. ISBN 978-92-9066-504-5.

Thomas M. D, Sissoko I, Sacko M. 1996. Development of leaf anthracnose and its effect on yield and grain weight of sorghum in west africa. Plant Disease, 80(2): 151-153.

Torres MH, Mendoza OL, Gonzalez HV, Williams AH. 1992. Reaction of tan and non-tan isogenic genotypes to head blight. International Sorghum Millets Newslett. 33, 36.

Turkan I, Demiral T. 2009. Recent developments in understanding salinity tolerance. Environmental and Experimental Botany, 67, 2-9.

UNDESA. 2017. United Nations epartment of Economic and Social Affairs. 2017. News. World population projected to reach 9.8 billion in 2050, and 11.2 billion in 2100 . https://www.un.org/development/desa/en/news/population/w orld-population-prospects-2017.html. Accessed 1.

Upadhyaya H. D, Wang Y.H, Rajan S, Shivali S. 2013. Identification of genetic markers linked to anthracnose resistance in sorghum using association analysis. Theory of Appled Genetics Journal, 126(6): 1649-1657. https://doi.org/10.1007/s00122-013-2081-1 
USDA-NASS. 2012. Census Full Report, avialble online https://www.nass.usda.gov/Publications/AgCensus/2012/ (Accessed 7, May 2020.

Valério HM, Resende MA, Weikert-Oliveira RCB, Casela CR. 2005. Virulence and molecular diversity in Colletotrichum graminicola from Brazil. Mycopathologia, 159, 449-459.

Vavilov N. 1992. Origin and geography of cultivated plants (V. Dorofeyev (Ed.)). Cambridge University Press, New York, NY, USA.

Vijayakumar MJayanthi C, Kalpana R, \& Ravisankar D. 2014. Integrated weed management in sorghum [Sorghum bicolor (L.) Moench]. Agricultural Review Journal, 35(2): 79-91.

Vincent M, Douglas M, Nyasha C, Never M, Godfrey C, Joseph M. 2013. An econometric approach to ascertain sorghum supply response in Zimbabwe. African Journal of Agricultural Research, 8(47): 6034-6038. https://doi.org/ 10.5897/AJAR12.7941

Visarada KBRS, Padmaja PG, Saikishore N, Pashupatinath E, Royer M, Seetharama N, Patil JV. 2014. Production and evaluation of transgenic sorghum for resistance to stem borer. In Vitro Cellular \& Developmental Biology - Plant, 50, 176189. https://doi.org/10.1007/s11627-013-9561-5

Viswanathan R, Samiyappan R. 2001. Red rot disease in sugarcane: challenges and prospects. Madras Agricultural Journal, 87: 549-559.
VonUexktill R, Mutert E, 1995. Global extent, development and economic impact of acid soils. Plant and Soil, 171, 1-15.

Wendorf F, Close A, Schild R, Wasylikowa K, Housley R, Harlan J, Królik, H. 1992. Saharan exploitation of plants 8,000 years bp. Nature, 359, 721-724.

Wharton P, Schilder A, 2008. Novel infection strategies of Colletotrichum acutatum on ripe blueberry fruit. Plant Pathology, 57, 122-134.

Wilfred V. 2008. A Primer on Genetics, Genomics and Plant Breeding.

Wingfield M, Slippers B, Roux J, Wingfield, B. 2001. Worldwide movement of exotic forest fungi, especially in the tropics and the southern hemisphere: This article examines the impact of fungal pathogens introduced in plantation forestry. BioScience, 51, 134-140.

Wollstein A, Herrmann A, Wittig M, Nothnagel M, Franke A, Nürnberg P, Schreiber S, Krawczak M, Hampe J. 2007. Efficacy assessment of SNP sets for genome-wide disease association studies. Nucleic Acids Reserach, 35, e113.

Wood S, Sebastian K, Scherr S. 2000. Agroecosystems. In C. Rosen (Ed.): in Pilot Analysis of Global Ecosystems: (pp. 4554). (International Food Policy Research Institute and the World Resources Institute, Washington, D.C.

Zhao C, Liu B, Piao S, Wang X, Lobell D, Huang Y, Huang M, Yao Y, Bassu S, Ciais P. et al. 2017. Temperature increase reduces global yields of major crops in four independent estimates. Proceeding of Natlonal Academy Society, USA, 114, 9326-9331. 